\title{
Regulatory T cells percentage in peripheral blood before and after eradication of Helicobacter pylori
}

\author{
Yuka Satoh $^{1}$, Hatsue Ogawara ${ }^{1^{*}}$, Osamu Kawamura $^{2}$, Yasuyuki Shimoyama $^{3}$, \\ Motoyasu Kusano ${ }^{3}$, Akihiko Yokohama ${ }^{4}$, Takayuki Saitoh ${ }^{5}$, Hiroshi Handa ${ }^{6}$, \\ Norifumi Tsukamoto ${ }^{7}$, Hirokazu Murakami ${ }^{5}$

\footnotetext{
${ }^{1}$ Faculty of Health Sciences, Gunma Paz College, Takasaki, Japan; * Corresponding Author: hmura@gunma-u.ac.jp

${ }^{2}$ Department of Medicine and Molecular Science, Gunma University Graduate School of Medicine, Maebashi, Japan

${ }^{3}$ Department of Endoscopy and Endoscopic Surgery, Gunma University Hospital, Maebashi, Japan

${ }^{4}$ Department of Blood Transfusion Service, Gunma University Hospital, Maebashi, Japan

${ }^{5}$ Department of Laboratory Sciences, Course of Health Sciences, Gunma Graduate School of Health Sciences, Maebashi, Japan

${ }^{6}$ Department of Medicine and Clinical Science, Gunma Graduate School of Medicine, Maebashi, Japan

${ }^{7}$ Oncology Center, Gunma University Hospital, Maebashi, Japan
}

Received 6 November 2013; revised 15 December 2013; accepted 23 December 2013

Copyright (C) 2014 Yuka Satoh et al. This is an open access article distributed under the Creative Commons Attribution License, which permits unrestricted use, distribution, and reproduction in any medium, provided the original work is properly cited. In accordance of the Creative Commons Attribution License all Copyrights ¿ 2014 are reserved for SCIRP and the owner of the intellectual property Yuka Satoh et al. All Copyright (C) 2014 are guarded by law and by SCIRP as a guardian.

\section{ABSTRACT}

Helicobacter pylori $(H$. pylori) induces gastroduodenal diseases and vigorous humural and cellular immune abnormalities. In order to clarify the immunological changes before and after eradication of $\boldsymbol{H}$. pylori, the percentages and ratios of the following cells in the peripheral blood of $32 \mathrm{H}$. pylori-infected patients and 25 control subjects were analyzed: CD4+ $T$ cells, CD8+ T cells, T helper 1 cells (Th1), T helper 2 cells (Th2), CD4+CD25+ T cells, Foxp3+ regulatory T cells (Treg), CD4/CD8 ratio, and Th1/Th2 ratio. CD4/CD8 ratio was significantly higher in $H$. pylori-infected patients before (mean \pm SD, $2.9 \pm$ 1.9) and after (mean \pm SD, $2.8 \pm 1.6$ ) eradication of $H$. pylori than in control subjects (mean \pm SD, $2.1 \pm 0.9$ ). The percentage of Th2 cells was significantly higher in $\boldsymbol{H}$. pylori-infected patients (mean \pm SD, $2.6 \pm 1.1$ ) than in control subjects (mean \pm SD, $1.9 \pm 1.1 ; p<0.02$ ). The percentage of Th2 cells after eradication of $H$. pylori (mean \pm SD, $2.3 \pm 1.4$ ) was lower than that before eradication. There was no significant difference between control subjects (mean $\pm \mathrm{SD}, 4.1 \% \pm 1.5 \%$ ) and patients before $\boldsymbol{H}$. pylori eradication (mean \pm SD, $4.5 \% \pm 2.4 \%$ ) in the percentage of Tregs, but the percentage was significantly higher in patients after $\boldsymbol{H}$. pylori eradication (mean \pm SD, $5.2 \%$ $\pm 2.6 \%$ ) than in control subjects. The function of peripheral induced Tregs was reported to sup- press the excessive immune reaction in chronic inflammation. These data suggest that Tregs may proliferate and be activated to suppress the activation of humoral immunity in $\mathrm{H}$. pylori-infected patients, and these changes continue after $\mathbf{3}$ months or later of successful eradication of H. pylori.

\section{KEYWORDS}

Helicobacter pylori; Regulatory T Cell; Th1 Cell; Th2 Cell

\section{INTRODUCTION}

Helicobacter pylori (H. pylori) is the most common pathogen of the gastrointestinal tract worldwide and the predominant cause of chronic gastritis, gastroduodenal ulcer, gastric lymphoma, and gastric cancer [1-3]. $H$. pylori is known to induce vigorous humoral and cellular immune responses. In gastric mucosa, $H$. pylori induces recruitment of CD4+ and CD8+ T cells and is suspected to be related to the pathogenesis of gastric inflammation [4]. In addition, $H$. pylori-induced pathology largely depends on Th1 cell-mediated responses and Th1 cytokines like IFN-gamma [5]. In the peripheral blood of $H$. pyloriinfected patients, conflicting data have been reported on the $\mathrm{B}$ and $\mathrm{T}$ cell subsets. Some investigators reported that there were no significant changes in the percentages of $\mathrm{B}$, CD4+ T, CD8+ T, or NK cells [6,7]. On the other hand, Soares et al reported that CD4+ T cells increased in $H$. 
pylori-infected patients [8]. We have reported that an increased CD4/CD8 ratio and a decreased Th1/Th2 ratio were observed in $H$. pylori-infected patients. Based on these data, we concluded that the activation of humoral immunity and Th2 polarization in peripheral blood were characteristic features of $H$. pylori-infected patients [9]. In this study, the peripheral blood $\mathrm{T}$ cell subsets before and after eradication of $H$. pylori were analyzed to determine the influence of $H$. pylori infection on the systemic immune response.

\section{PATIENTS AND METHODS}

\subsection{Patients}

This study was performed with approval from the Human Research Ethical Committee of Gunma University Hospital, and all patients and volunteers gave their informed consent. Thirty-two $\mathrm{H}$. pylori-infected patients diagnosed at Gunma University Hospital between 2007 and 2012 were included in this study. The median age of the patients was 58.8 years (range, 22 - 81 years), and the male/female ratio was 26/6. $H$. pylori infection was established by the following criteria: positive tests for urease breath test and/or biopsy sample of the stomach. All patients were treated with lansoprazole $30 \mathrm{mg}$ bid, amoxicillin hydrate $750 \mathrm{mg}$ bid, and clarithromycin 200 mg bid for 7 days, and 29 patients achieved successful eradication. The other 3 patients failed to achieve H. pylori eradication and were consequently treated with rabeprazole $10 \mathrm{mg}$ bid, amoxicillin hydrate $750 \mathrm{mg}$ bid, and metronidazole $250 \mathrm{mg}$ bid for 7 days; complete eradication of $H$. pylori was achieved after the second eradication therapy. The completion of eradication was confirmed by the urease breath test and/or serum anti- $H$. pylori IgG antibody (Eiken Chemical Co., Ltd, Tokyo, Japan).

Controls were obtained from $25 \mathrm{H}$. pylori-uninfected donors who were negative for serum anti- $H$. pylori IgG antibody. The male/female ratio of controls was 1.1 (13/ 12), and their median age was 43.4 years (range, 22 - 65 years). The clinical data for study subjects are shown in Table 1. The analyses of peripheral blood $\mathrm{T}$ lymphocyte subsets were performed before and at least 3 months after eradication of $H$. pylori.

\subsection{Measurement of the CD4/CD8 Ratio}

Peripheral blood cells were collected using ethylenediaminetetraacetic acid-3K. Lymphocytes were labeled using the following monoclonal antibodies: CD45-FITC/ CD4-RD1/CD8-ECD/CD3-PC5 (Cyto-Stat tetraCHROME monoclonal antibodies, BD Pharmingen, San Jose, CA), and subsets were analyzed by 3-color flow cytometer using an EPICS XL System II (Beckman Coulter, Fullerton, CA).
Table 1. Characteristics of participants in this study.

\begin{tabular}{cccc}
\hline & Control & $\begin{array}{c}\text { Before } \\
\text { eradication }\end{array}$ & $\begin{array}{c}\text { After } \\
\text { eradication }\end{array}$ \\
\hline Cases (n) & 25 & \multicolumn{2}{c}{32} \\
Sex (male:female) & $(13: 12)$ & \multicolumn{2}{c}{$(26: 6)$} \\
$\begin{array}{c}\text { Age median: } \\
\text { range (year) }\end{array}$ & $43.4: 22-65$ & $58.8: 22-81$ \\
Hemoglobin (g/dl) & $13.7 \pm 1.2$ & $14.0 \pm 1.2$ & $14.1 \pm 1.2$ \\
Hematocrit $(\%)$ & $41.2 \pm 3.9$ & $41.4 \pm 3.5$ & $41.8 \pm 3.6$ \\
WBC $\left(\times 10^{9} / 1\right)$ & $5.8 \pm 1.6$ & $6.5 \pm 2.2$ & $6.2 \pm 2.3$ \\
Neutrophils $\left(\times 10^{9} / 1\right)$ & $3.4 \pm 1.3$ & $4.0 \pm 1.7$ & $3.6 \pm 1.9^{*}$ \\
Monocytes $\left(\times 10^{9} / 1\right)$ & $0.33 \pm 0.12$ & $0.37 \pm 0.14$ & $0.36 \pm 0.14$ \\
Lymphocytes $(\times 109 / 1)$ & $1.8 \pm 0.5$ & $1.8 \pm 0.5$ & $1.9 \pm 0.6$ \\
Platelets $(\times 109 / \mathrm{l})$ & $231 \pm 51$ & $235 \pm 56$ & $222 \pm 56^{*}$ \\
\hline
\end{tabular}

Mean \pm SD, ${ }^{*}$ p values $<0.05$ as compared with before eradication.

\subsection{Measurement of the Th1/Th2 Ratio}

Whole heparinized blood was mixed with an equal volume of RPMI1640 medium and incubated at $37^{\circ} \mathrm{C}$ with $7 \% \mathrm{CO}_{2}$ for 4 hours with $25 \mathrm{ng} / \mathrm{mL}$ phorbol 12-myristate 13-acetate (Sigma-Aldrich, St. Louis, MO), $1 \mu \mathrm{g} / \mathrm{mL}$ ionomycin, and $10 \mu \mathrm{g} / \mathrm{mL}$ Brefeldin A (Sigma-Aldrich). After treatment with FACS lysing solution and FACS permeabilizing solution (BD Biosciences, San Jose, CA), cells were stained at $4^{\circ} \mathrm{C}$ for $30 \mathrm{~min}$ with antihuman CD4-PECy5 (BD Pharmingen), FastImmune fluorescein isothiocyanate (FITC)-labeled antihuman IFN- $\gamma$, and phycoerythrin-(PE-) labeled antihuman IL-4 (BD Biosciences). FastImmune IgG2a FITC/IgG1 PE isotype controls (BD Biosciences) were used as negative controls for human IFN- $\gamma$ and IL-4. Three-color flow cytometric analysis was performed on FACS Calibur flow cytometer using Cell Quest software (BD Biosciences).

\subsection{Regulatory T cell (Treg) Measurements}

PE-Cy5 antihuman CD4 monoclonal antibody (BD Pharmingen) and FITC antihuman CD25 (BD Biosciences) were used for surface antigen staining. Mouse IgG1, $\kappa$-FITC (BD Pharmingen) was used as an isotype control. PEconjugated antihuman Foxp3 (PCH101) and PE-conjugated rat IgG2a isotype control from eBiosciences (San Diego, CA) were used for intracellular Foxp3 staining according to the manufacturer's instructions. Tregs were defined as CD4+CD25+Foxp3+ cells. Measurement of Tregs was performed by 3-color flow cytometry as described above for Th1/Th2 ratio.

\subsection{Complete Blood Cell Count}

Complete blood cell counts were performed using a 
total blood analyzer (ADVIA 120, Siemens, Tarrytown, NY).

\subsection{Statistical Analysis}

Data analysis was performed using SPSS statistics 17.0 (IBM, Armonk, NY). Comparisons of control and patients before eradication were performed using a nonparametric test (Mann-Whitney U test). Comparisons of patients before and after eradication were performed using a non-parametric test (Wilcoxon test). P values $<0.05$ were considered significant.

\section{RESULTS}

\subsection{Clinical Data of Control Subjects and Patients before and after $\boldsymbol{H}$. pylori Eradication (Table 1)}

White blood cell, neutrophil, monocyte, lymphocyte, and platelet counts were statistically identical in $H$. pylori-infected patients and control subjects. The white blood cell count tended to decrease after eradication of $H$. pylori (mean $\pm \mathrm{SD}, 6.2 \pm 2.4 \times 10^{9} / \mathrm{L}$ ) compared to that before eradication (mean $\pm \mathrm{SD}, 6.5 \pm 2.2 \times 10^{9} / \mathrm{L}$; p = $0.06)$. The neutrophil count was significantly lower after eradication of $H$. pylori (mean $\pm \mathrm{SD}, 3.6 \pm 1.9 \times 10^{9} / \mathrm{L}$ ) compared to that before eradication (mean \pm SD, $4.0 \pm$ $\left.1.7 \times 10^{9} / \mathrm{L} ; \mathrm{p}<0.02\right)$. The platelet count was significantly lower after eradication of $H$. pylori (mean $\pm \mathrm{SD}$, $222 \pm 56 \times 10^{9} / \mathrm{L}$ ) than before eradication (mean $\pm \mathrm{SD}$, $\left.235 \pm 56 \times 10^{9} / \mathrm{L} ; \mathrm{p}=0.04\right)$. The hemoglobin level and monocytes and lymphocyte counts showed no significant differences between before and after $H$. pylori eradication.

\subsection{CD4/CD8 Ratio before and after Eradication of $H$. pylori}

The CD4/CD8 ratio was significantly higher in $H$. pylori-infected patients (mean $\pm \mathrm{SD}, 2.9 \pm 1.9$ ) than in control subjects (mean $\pm \mathrm{SD}, 2.1 \pm 0.9$; $<<0.05$ ). The ratio after eradication of $H$. pylori (mean $\pm \mathrm{SD}, 2.8 \pm 1.6$ ) was also significantly higher than in control subjects ( $\mathrm{p}<$ 0.02) (Figure 1).

\subsection{The Percentage of Th1 Cells and Th2 Cells, and the Th1/Th2 Ratio}

There was no significant difference in the percentage of Th1 cells between before and after eradication of $H$. pylori (mean \pm SD, $21.4 \pm 7.5$ vs. $20.4 \pm 9.1$ ) (Figure 2(a)). The percentage of Th2 cells was significantly higher in $H$. pylori-infected patients (mean \pm SD, $2.6 \pm$ 1.1) than in control subjects (mean \pm SD, $1.9 \pm 1.1$; p < 0.02 ). The percentage of Th2 cells after eradication of $H$. pylori (mean $\pm \mathrm{SD}, 2.3 \pm 1.4$ ) was lower than before era-

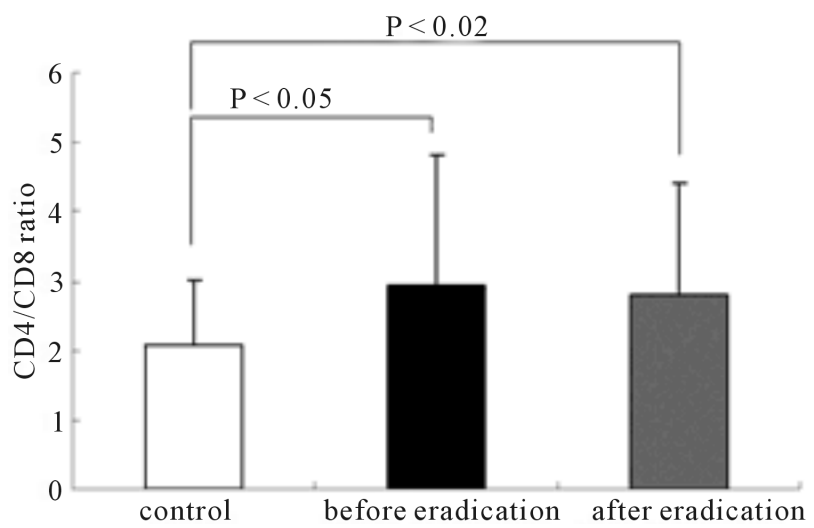

Figure 1. Comparison of CD4/CD8 ratios. White, black, and oblique line columns represent the CD4/CD8 ratios of control subjects, $H$. pylori-infected patients before eradication, and $H$. pylori-infected patients after eradication, respectively. The ratio is significantly higher in $H$. pylori-infected patients before and after eradication (mean \pm SD, $2.9 \pm 1.9$ and $2.8 \pm 1.6$ ) than in control subjects (mean $\pm \mathrm{SD}, 2.1 \pm 0.9 ; \mathrm{p}<0.05$ and $\mathrm{p}<0.02$, respectively). There is no significant difference between before and after $H$. pylori eradication. Data are given as means \pm SD.

dication (mean $\pm \mathrm{SD}, 2.6 \pm 1.1$ ) (Figure 2(b)). The Th1/Th2 ratio was lower in $H$. pylori-infected patients than in control subjects (mean \pm SD, $11.9 \pm 12.5$ vs. 13.3 \pm 8.8 ); however there was no significant difference. The ratio after eradication of $H$. pylori (mean \pm SD, $14.7 \pm$ 13.4) was higher than before eradication of $H$. pylori (mean $\pm \mathrm{SD}, 13.3 \pm 8.8$ ) (Figure 3); however there was no significant difference.

\subsection{Percentage CD4+CD25+ and CD4+CD25+ Foxp3+ T Cells}

The percentage of CD4+CD25+ T cells was significantly higher in patients before eradication of $H$. pylori (mean $\pm \mathrm{SD}, 14.8 \% \pm 6.0 \%$ ) than in control subjects (mean \pm SD, $12.2 \% \pm 6.6 \%$; $<<0.05$ ). The percentage was also significantly higher after eradication of $H$. pylori (mean $\pm \mathrm{SD}, 17.4 \% \pm 6.6 \%$ ) than in control subjects $(\mathrm{p}<0.01)$ (Figure 4(a)). This population includes both activated CD4+ $\mathrm{T}$ cells and Tregs and, thus, changes in Tregs could be masked in this impure population. To measure the percentages of Tregs, the frequency of CD4+CD25+ Foxp3+ T cells was monitored. There was no significant difference in the percentage of Tregs between control subjects (mean $\pm \mathrm{SD}, 4.1 \% \pm 1.5 \%$ ) and patients before eradication of $H$. pylori (mean $\pm \mathrm{SD}, 4.5 \%$ $\pm 2.4 \%$ ). The percentage was significantly higher in patients after eradication of $H$. pylori (mean \pm SD, $5.2 \% \pm$ 2.6\%) than in control subjects (Figure 4(b)).

\section{DISCUSSION}

In addition to gastrointestinal disease, $H$. pylori is associated with several systemic autoimmune diseases 


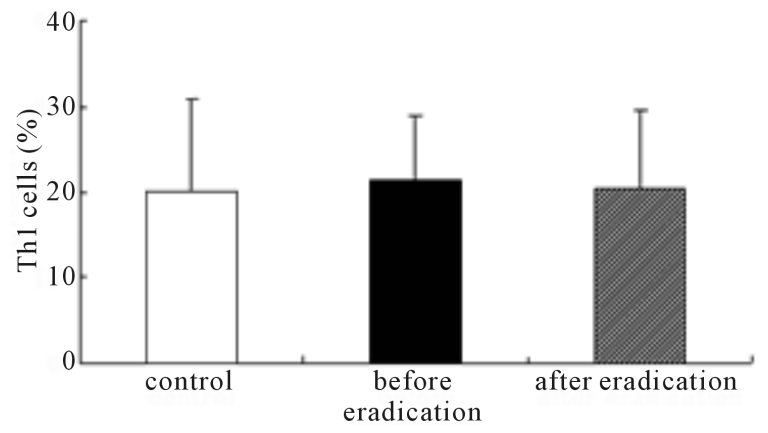

(a)

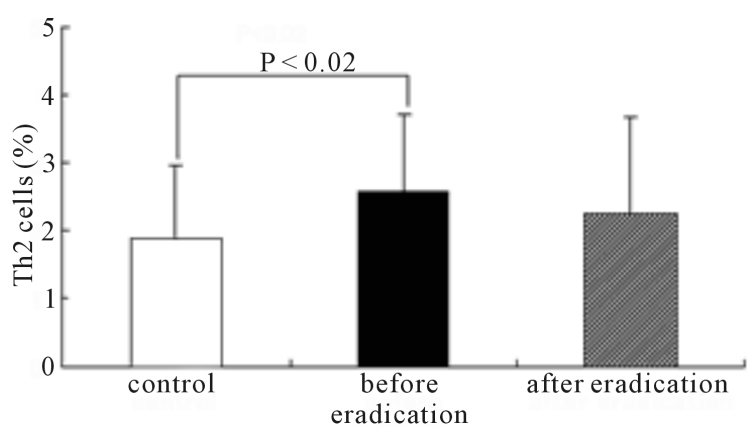

(b)

Figure 2. White, black, and oblique line columns represent the percentages of Th1 cells and Th2 cells of control subjects, $H$. pylori-infected patients before eradication, and $H$. pylori-infected patients after eradication, respectively. Data are given as means \pm SD. (a) Comparison of the percentage of Th1 cells. There are no significant differences among control subjects, $H$. pylori-infected patients before eradication, and $H$. pylori-infected patients after eradication. (b) Comparison of the percentage of Th2 cells. The percentage is significantly higher in $\mathrm{H}$. pylori-infected patients (mean $\pm \mathrm{SD}, 2.6 \% \pm 1.1 \%$ ) than in control subjects (mean $\pm \mathrm{SD}, 1.9 \% \pm 1.1 \%$; $\mathrm{p}<0.02$ ). There is no significant difference in the percentage of Th2 cells before and after eradication of $H$. pylori.

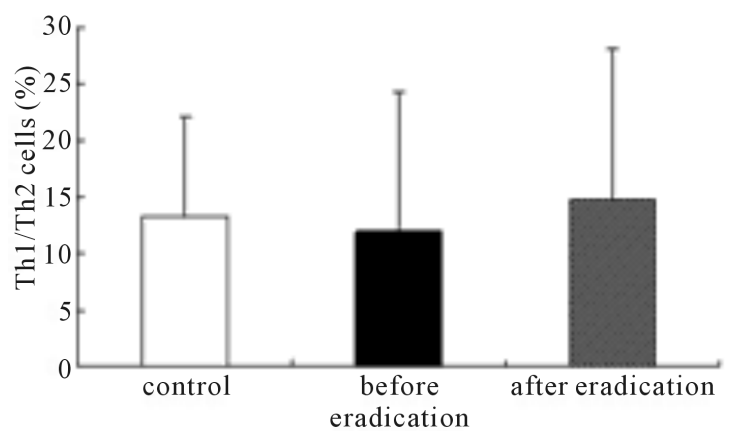

Figure 3. Comparison of the Th1/Th2 ratio. White, black, and oblique line columns represent the Th1/Th2 ratios of control subjects, $H$. pylori-infected patients before eradication, and $H$. pylori-infected patients after eradication, respectively. Data are given as means \pm SD. The Th1/Th2 ratio is lower in $H$. pylori-infected patients than in control subjects, but there is no significant difference in the Th1/Th2 ratio between before and after eradication of $H$. pylori.

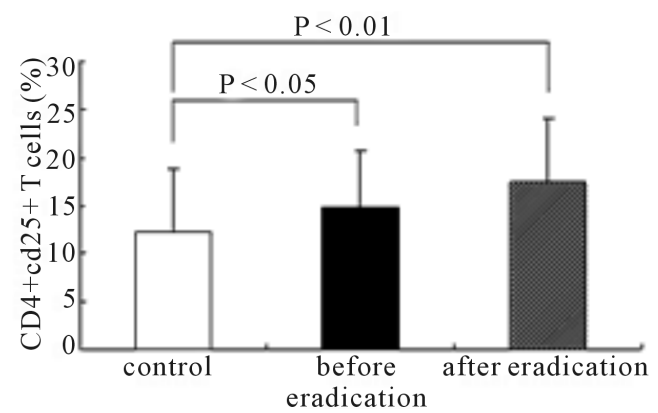

(a)

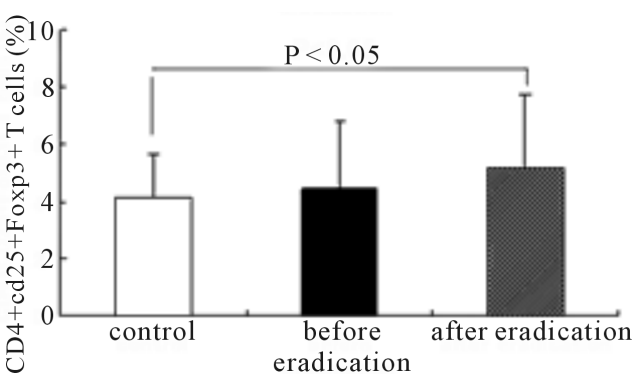

(b)

Figure 4. White, black, and oblique line columns represent the percentages of CD4+CD25+ T cells and CD4+CD25+Foxp3+ T cells of control subjects, $H$. pylori-infected patients before eradication, and $H$. pylori-infected patients after eradication, respectively. Data are given as means \pm SD. (a) Comparison of the percentage of CD4+CD25+ T cells. The percentage of CD4+CD25+ T cells is significantly higher in patients before eradication of $H$. pylori (mean $\pm \mathrm{SD}, 14.8 \% \pm 6.0 \%$ ) than in control subjects (mean \pm SD, $12.2 \% \pm 6.6 \%$; $p<$ 0.05 ). The percentage is also significantly higher after eradication of $H$. pylori (mean \pm SD, $17.4 \%$ $\pm 6.6 \%)$ than in control subjects $(p<0.01)$. Comparison of the percentage of CD4+CD25+Foxp3+ $\mathrm{T}$ cells. There is no significant difference between control subjects (mean $\pm \mathrm{SD}, 4.1 \% \pm 1.5 \%$ ) and patients before $H$. pylori eradication (mean \pm SD, $4.5 \% \pm 2.4 \%$ ). The percentage is significantly higher in patients after $H$. pylori eradication (mean $\pm \mathrm{SD}, 5.2 \% \pm 2.6 \%$ ) than in control subjects $(\mathrm{p}<0.05)$.

(Sjögren's syndrome [10], and systemic sclerosis [11]), and organ-specific autoimmune diseases (idiopathic thrombocytopenic purpura [12], Graves’ disease [13], and autoimmune pancreatitis [14]). Given this association with autoimmune diseases, we hypothesized that $H$. $p y$ lori might induce systemic immunological changes. Therefore, we compared the immune characteristics of peripheral blood of $H$. pylori-infected patients and control subjects, and we reported activation of humoral immunity and Th2 polarization in $H$. pylori-infected patients [9]. Based on these data, we suspected that these abnormalities may induce systemic autoimmune diseases. 
We have already reported that the frequency of Th1, Th2, and Treg cells was not associated with aging [15, $16]$, so that we compared the frequency of these cells between $H$. pylori-infected patients and control subjects regardless of the difference of age distribution.

Kodama et al. reported that cultures and histological examinations of stomach were performed 6 months after eradication in $H$. pylori-infected patients and revealed a significant decrease of inflammatory activity in the stomach [17]. Watanabe et al reported that the gastric atrophy due to $H$. pylori improved gradually, but moderate or marked gastric inflammation improved 6 weeks after eradication of $H$. pylori [18]. Fichman and Niv also reported rapid improvement of acute and chronic inflammation of the stomach 3 months after the eradication of H. pylori [19]. Based on these reports, we analyzed the immunological abnormalities before and 3 months or later after the eradication of $H$. pylori in order to determine whether the immunological abnormalities recover after successful eradication.

White blood cell, neutrophil, and lymphocyte counts have been reported to increase in $H$. pylori-infected patients $[20,21]$. In the present study, these counts were slightly higher in $H$. pylori-infected patients than in control subjects, and they decreased after eradication of $H$. pylori. It is suspected that this decrease was induced by the improvement of inflammation due to $H$. pylori.

Yuceyar et al. reported that there was no significant difference in peripheral blood lymphocyte subsets between $H$. pylori-infected patients and control subjects [7], but we have reported a decrease in the percentage of CD8+ $\mathrm{T}$ cells and an increase in the CD4/CD8 ratio in peripheral blood lymphocytes of $H$. pylori-infected patients [9]. We suspected that the distribution of CD8+ T cells changes in $H$. pylori-infected patients, with migration of peripheral CD8+ T cells into the gastric mucosa, based on the reports that showed CD8+ T cell accumulation in the gastric mucosa, which increases the severity of gastric inflammation. However, the increase of CD4/8 ratio sustained after successful eradication of $H$. pylori.

We also reported Th2 polarization and suspected that peripheral blood Th1 cells migrate to the gastric mucosa in $H$. pylori-infected patients, because D'Elios showed that $H$. pylori-specific Th1 cells could be cloned from $H$. pylori-infected gastric mucosa and that these cells were cytotoxic to gastric epithelial cells because they produced IFN-gamma [5].

Tregs have a crucial role in suppressing immune responses to self-antigens, preventing autoimmune diseases, and in controlling immune responses to pathogens [22]. Their local infiltration into the gastric mucosa of $H$. pylori-infected patients suggested their involvement in suppressing mucosal immune responses, contributing to the persistence of infection [23-26]. Lundgren et al. re- ported that $H$. pylori-infected patients have an impaired memory CD4+ T cell response to $H$. pylori that is linked to the presence of $H$. pylori-specific CD4+CD25+ T cells in peripheral blood, which actively suppress the response [27]. In the present study, the percentage of CD4+CD25+ $\mathrm{T}$ cells was significantly higher in $H$. pylori-infected patients and successfully eradicated patients than in control subjects. In addition, the percentage of Treg

(CD4+CD25+Foxp3+ T cells) was higher in $H$. pyloriinfected patients than in control subjects, and it was significantly higher in successfully eradicated patients than in control subjects. The function of peripheral induced Tregs was reported to suppress the excessive immune reaction in chronic inflammation. These data suggest that Tregs may proliferate and be activated to suppress the activation of humoral immunity in $H$. pylori-infected patients, and these changes continue after 3 months or later of successful eradication of $H$. pylori.

We have expected the decrease of Tregs in $H$. pyloriinfected patients, because $H$. pylori is associated with several systemic autoimmune diseases. Tregs were reported to be composed of natural Tregs and induced Tregs. Natural Tregs are produced by the thymus as an antigen-primed and functionally mature $\mathrm{T}$ cell subpopulation specialized for self-tolerance. Induced Tregs are produced by the peripheral lymph-nodes in response to the external antigens in chronic infection, and are composed of some subsets including $\mathrm{T}$ helper 3 (Th3) and type 1 regulatory $\mathrm{T}$ ( $\mathrm{Tr} 1)$ cells. The lasting increase of Tregs might be due to the difference of the subtype of Tregs, and depend on the increase of Th3 which is responsible for mucosal immunity in $H$. pylori-infected patients.

\section{CONCLUSION}

These data suggest that Tregs may proliferate and be activated to suppress the activation of humoral immunity in $H$. pylori-infected patients, and these changes continue after 3 months or later of successful eradication of $H$. pylori.

\section{CONFLICT OF INTERESTS}

The authors have no conflict of interest to declare.

\section{ACKNOWLEDGEMENTS}

The authors would like to thank the patients and volunteers who agreed to participate in this study.

\section{REFERENCES}

[1] Megraud, F. and Lamouliatte, H. (1992) Helicobacter and duodenal ulcer. Digestive Diseases and Sciences, 37, 769772. http://dx.doi.org/10.1007/BF01296437 
[2] Parsonnet, J., Freidman, G.D. and Vandersteen D.P. (1991) Helicobacter pylori infection and the risk of gastric carcinoma. The New England Journal of Medicine, 325, 11271131. http://dx.doi.org/10.1056/NEJM199110173251603

[3] Parsonnet, J., Hansen, S. and Rodriguez, L. (1994) Helicobacter pylori infection and gastric lymphoma. The New England Journal of Medicine, 330, 1267-1271. http://dx.doi.org/10.1056/NEJM199405053301803

[4] Fan, X.J., Chua, A., Shahi, C.N., McDevitt, J., Keeling, P.W. and Kelleher, D. (1994) Gastric T lymphocyte responses to Helicobacter pylori in patients with $H$. pylori colonization. Gut, 35, 1379-1384. http://dx.doi.org/10.1136/gut.35.10.1379

[5] D’Elios, M.M., Manghetti, M., Almerigogna, F., Amedei, A., Costa, F. Burroni, D., et al. (1997) Different cytokine profile and antigen-specificity repertoire in Helicobacter pylori-specific T cell clones form the antrum of chronic gastritis patients with or without peptic ulcer. European Journal of Immunology, 27, 1750-1755. http://dx.doi.org/10.1002/eji.1830270723

[6] Kayhan, B., Araslin, M., Eren, H., Aydemir, S., Kayhan, B. and Aktas, E. (2008) Analysis of peripheral blood lymphocyte phenotype and Th1/Th2 cytokines profile in the systemic immune responses of Helicobacter pyloriinfected individuals. Microbiology and Immunology, 52, 531-538. http://dx.doi.org/10.1111/j.1348-0421.2008.00066.x

[7] Yuceyar, H., Kokuludag, A., Tezioglu, E., Goksei, G. and Isisag, A. (2002) The systemic cellular immune response in the Helicobacter pylori-associated duodenal ulcer and chronic antral gastritis. Hepatogastroenterology, 49, 11771179.

[8] Soares, T.F., Rocha, G.A., Rocha, A.M.C., Correa-Oliveira, R., Martins-Filho, O.A., Carvalhos, A.S.T., et al. (2005) Phenotypic study of peripheral blood lymphocytes and humoral immune response in Helicobacter pylori infection according age. Scandinavian Journal of Immunology, 62, 63-70. http://dx.doi.org/10.1111/j.1365-3083.2005.01638.x

[9] Satoh, Y., Ogawara, H., Kawamura, O., Kusano, M. and Murakami, H. (2012) Clinical significance of peripheral blood T lymphocyte subsets in Helicobacter pylori-infected patients. Gastroenterology Research and Practice, 2012, Article ID: 819842. http://dx.doi.org/10.1155/2012/819842

[10] El Miedany, Y.M., Baddour, M., Ahmed, I. and Fahmy, H. (2005) Sjogren's syndrome: Concomitant $H$. pylori infection and possible correlation with clinical parameters. Joint Bone Spin, 72, 135-141. http://dx.doi.org/10.1016/j.jbspin.2004.04.005

[11] Radic, M., Kaliterna, D.M. and Radic, J. (2010) Helicobacter pylori infection and systemic sclerosis-is there a link? Joint Bone Spine, 78, 337-340. http://dx.doi.org/10.1016/j.jbspin.2010.10.005

[12] Stasi, R., Sarpatwari, A., Segal, J.B., Osborn, J., Evangelista, M.L., Cooper, N., et al. (2009) Effects of eradication of Helicobacter pylori infection in patients with immune thrombocytopenic purpura: A systemic review. Blood, 113, 1231-1240.

\section{http://dx.doi.org/10.1182/blood-2008-07-167155}

[13] Basi, V., Santinelli, C., Lengo, A. and Romano, C. (2010) Identification of a correlation between Helicobacter pylori infection and Graves' disease. Helicobacter, 15, 558562. http://dx.doi.org/10.1111/j.1523-5378.2010.00802.x

[14] Jesnowski, R., Isaksson, B., Mohrchke, C., Bertsch, C., Bulajic, M., Schneider-Brachert, W., et al. (2010) Helicobacter pylori in autoimmune pancreatitis and pancreatic carcinoma. Pancreatology, 10, 462-466. http://dx.doi.org/10.1159/000264677

[15] Murakami, H., Yamane, A., Sawamura, M., Matsumoto, M., Murayama, K., Shimano, S., et al. (2005) High Th1/ Th2 ratio in patients with multiple myeloma. Leukemia Research, 29, 135-140. http://dx.doi.org/10.1016/j.leukres.2004.06.003

[16] Hamdi, W., Ogawara, H., Handa, H., Tsukamoto, N., Nojima, Y. and Murakami, H. (2009) Clinical significance of regulatory $\mathrm{T}$ cells in patients with myelodysplastic syndrome. European Journal of Haematology, 82, 201-207. http://dx.doi.org/10.1111/j.1600-0609.2008.01182.x

[17] Kodama, M., Murakami, K., Okimoto, T., Sato, R., Uchida, M., Abe, T., et al. (2012) Ten-year prospective follow-up of histological changes at five points on the gastric mucosa as recommended by the updated Sydney system after Helicobacter pylori eradication. Journal of Gastroenterology, 47, 394-403. http://dx.doi.org/10.1007/s00535-011-0504-9

[18] Watanabe, Hm, Yamaguchi, Nm, Kuwayama, H., Sekinem C, Uemuram N., Kaise, M., et al. (2003) Improvement in gastric histology following Helicobacter pylori eradication therapy in Japanese peptic ulcer patients. Journal of International Medical Research, 31, 362-369. http://dx.doi.org/10.1177/147323000303100502

[19] Fichman, S. and Niv, Y. (2994) Histological changes in the gastric mucosa after Helicobacter pylori eradication. European Journal of Gastroenterology \& Hepatology, 16, 1183-1188. http://dx.doi.org/10.1097/00042737-200411000-00017

[20] Kondo, Y., Joh, T., Sasaki, M., Oshima, T., Itoh, K., Tanida, S., et al. (2004) Helicobacter pylori eradication decreases blood neutrophil and monocyte counts. Alimentary Pharmacology \& Therapeutics, 20, 74-79. http://dx.doi.org/10.1111/j.1365-2036.2004.01988.x

[21] Karttunen, T.J., Niemela, S. and Kerola, T. (1996) Blood leukocyte differential in Helicobacter pylori infection. Digestive Diseases and Sciences, 41, 1332-1336. http://dx.doi.org/10.1007/BF02088556

[22] Mills, K.H. (2004) Regulatory T cells: Friend or foe in immunity to infection? Nature Reviews Immunology, 4, 841-855. http://dx.doi.org/10.1038/nri1485

[23] Lundgren, A., Strömberg, E., Sjöling, A., Lindholm, C., Enarsson, K., Edebo, A., et al. (2005) Mucosal Foxp3expressing CD4+CD25high regulatory $\mathrm{T}$ cells in Helicobacter pylori-infected patients. Infection and Immunity, 73, 523-531.

http://dx.doi.org/10.1128/IAI.73.1.523-531.2005 
[24] Perrone, G., Ruffini, P.A., Catalano, V., Spino, C., Santini, D., Muretto, P., et al. (2008) Intratumoural Foxp3-positive regulatory $\mathrm{T}$ cells are associated with adverse prognosis in radically resected gastric cancer. European Journal of Cancer, 44, 1875-1882.

http://dx.doi.org/10.1016/j.ejca.2008.05.017

[25] Kindlund, B., Sjöling, A., Hansson, M., Edebo, A., Hanson, L.E., Sjövall, H., et al. (2009) Foxp3-expressing CD4+ T-cell numbers increase in areas of duodenal gastric metaplasia and are associated to CD4+ T-cell aggregates in the duodenum of Helicobacter pylori-infected duodenal ulcer patients. Helicobacter, 14, 192-201. http://dx.doi.org/10.1111/j.1523-5378.2009.00673.x
[26] Chen, T., Jin, R., Huang, Z., Hong, W., Chen, Z. and Wang, J. (2010) The variation of expression of CD4+ CD25+ Foxp3+ regulatory $\mathrm{T}$ cells in patients with $\mathrm{He}$ licobacter pylori infection and eradication. Hepatogastroenterology, 57, 430-435.

[27] Lundgren, A., Suri-Payer, E., Enarsson, K., Svennerholm, A.-M. and Lundin, B.S. (2003) Helicobacter pylori-specific CD4+ CD25high regulatory $\mathrm{T}$ cells suppress memory T-cell responses to $H$. pylori in infected individuals. Infection and Immunity, 71, 1755-1762. http://dx.doi.org/10.1128/IAI.71.4.1755-1762.2003 